University of Texas Rio Grande Valley

ScholarWorks @UTRGV

Winter 11-20-2020

\title{
Intraoperative ICG-NIR Fluorescence Angiography Visualization of Testicular Perfusion in Operations for Testicular Torsion
}

\author{
Colton D. Wayne \\ The University of Texas Rio Grande Valley, colton.wayne01@utrgv.edu \\ Mohammad A. Emran \\ Driscoll Children's Hospital \\ Leon Smith-Harrison \\ Driscoll Children's Hospital \\ P. Stephen Almond \\ Driscoll Children's Hospital \\ Haroon I. Patel \\ Driscoll Children's Hospital
}

See next page for additional authors

Follow this and additional works at: https://scholarworks.utrgv.edu/som9331

Part of the Surgery Commons, and the Urology Commons

\section{Recommended Citation}

Wayne, C. D., Emran, M. A., Smith-Harrison, L., Stephen Almond, P., \& Omar Cruz-Diaz, M. (2020). Intraoperative ICG-NIR Fluorescence Angiography Visualization of Testicular Perfusion in Operations for Testicular Torsion. Journal of the American College of Surgeons, 231(4), e179. https://doi.org/10.1016/ j.jamcollsurg.2020.08.473

This Article is brought to you for free and open access by the School of Medicine at ScholarWorks @ UTRGV. It has been accepted for inclusion in MEDI 9331 Scholarly Activities Clinical Years by an authorized administrator of ScholarWorks@ UTRGV.For more information, please contact justin.white@utrgv.edu, william.flores01@utrgv.edu. 


\section{Authors}

Colton D. Wayne, Mohammad A. Emran, Leon Smith-Harrison, P. Stephen Almond, Haroon I. Patel, and Shannon Koehler 


\title{
Intraoperative ICG-NIR Fluorescence Angiography Visualization of Testicular Perfusion in Operations for Testicular Torsion
}

\author{
Colton D. Wayne BS, Mohammad A. Emran MD, Leon Smith-Harrison MD, P. Stephen Almond MD, \\ Haroon I. Patel MD, Shannon Koehler MD
}

Purpose: Indocyanine Green (ICG) near-infrared (NIR) fluorescence angiography is used in assessing testicular perfusion after reduction of testicular torsion to assess tissue viability.

Introduction: Determination of viability of a testicle after reduction of a testicular torsion has been performed by numerous methods including visual assessment, Doppler ultrasound, and cutting the testicular capsule. Each of these has limitations, are not always reproducible, and may involve damage to the testicle and confusion of capsular blood flow for internal perfusion. A possible alternative to these methods is the use of ICG-NIR fluorescence angiography. ICG was FDA-approved in 1959 and has been in use for over 60 years across various fields including colorectal and breast surgery, with few reported adverse events related to the injectable dye. Intraoperative use of an NIR camera causes the dye to fluoresce. ICG -NIR is used in this report to demonstrate the perfusion or lack thereof during reduction of testicular torsion.

Method: Thirty patients in a single center presented with testicular torsion from November 2015 August 2019, and were evaluated by a combination of 3 Pediatric Surgeons and 2 Pediatric Urologists using ICG-NIR during torsion reduction procedures. An anesthesiologist injected $1.25 \mathrm{mg}(<2 \mathrm{mg} / \mathrm{kg})$ ICG dye intravenously and the surgeon used the NIR camera to visualize the testicle In-situ to assess the local perfusion before and after testicle reduction. After investigation of testicle viability, the surgeon determined whether to proceed with an orchiopexy or orchiectomy based on tissue perfusion.

Results: Thirty patients in a single center presented with testicular torsion from November 2015 August 2019, and were evaluated by a combination of 3 Pediatric Surgeons and 2 Pediatric Urologists using ICG-NIR during torsion reduction procedures. This process identified the extent of perfusion and differentiated capsular from internal testicular perfusion. It provided assurance of blood flow or definitively confirmed lack of tissue viability, allowing surgeons to proceed with orchiopexies or orchiectomies, respectively. ICG-NIR findings were correlated with standard methods of assessing testicular perfusion, and all patients received contralateral orchiopexy.

Conclusion: In patients presenting with testicular torsion, the determination of testicular viability after reduction is very subjective, and complication risk from the surgery can vary based numerous factors including surgeon level of experience, method utilized to assess perfusion, and hemodynamic status of the patient. Use of technologies that image vascular irrigation prior to decision to resect or leave the testicle in place may help to reduce these complications. This study was limited by small sample size in a single center. Future studies with higher volume should compare postoperative complications using this technology compared to other accepted methods of assessing testicle perfusion. This will help elucidate benefits to current surgical outcomes, as well as to gauge success of future novel techniques used in testicular salvage during torsion reductions. 